\title{
MULTIMODAL COMMUNICATION ANALYSIS: THE HIGHER-LEVEL ACTIONS OF WAITERS AND WAITRESSES AT THREE RESTAURANTS IN TABANAN
}

\author{
Rama Urif Sukma Nugraha \\ English Language Education, Universitas Pendidikan Ganesha \\ e-mail: ramaurif.sukma@gmail.com \\ I Putu Ngurah Wage Myartawan \\ English Language Education, Universitas Pendidikan Ganesha \\ e-mail: wmyartawan@gmail.com \\ Dewa Ayu Eka Agustini \\ English Language Education, Universitas Pendidikan Ganesha \\ e-mail: dewayu_eka@yahoo.com
}

\begin{abstract}
This study aimed to analyze the multimodal communication of waiters and waitresses at three restaurants in Tabanan, Bali Province, in applying higher-level actions in serving foreign guests and investigating the functions of the higher-level actions of waiters and waitresses in serving the foreign guests. This study used theories proposed by Fishman (1972) cited in Suandi \& Indriani (2016) on functions of using verbal and nonverbal communication, Krees and Van Leewuen 2006) on multimodal communication, and Norris (2004) on higher-level actions. The subjects of this study were four waiters and two waitresses who were working at three different restaurants in Tabanan regency. The results of this study showed that in each conversation, there were many sequences of higher-level actions used by waiters or waitresses to serve the foreign guests. The waiters and waitresses used a sequence of modes alternately or simultaneously in their higherlevel actions, depending on the situation. The functions of waiters or waitresses' higher-level actions in serving foreign guests made their messages clearer to foreign guests, and this made the waiters or waitresses' messages more believable to the foreign guests.
\end{abstract}

Key words: multimodal communication, verbal communication, nonverbal communication, higher-level actions

\section{INTRODUCTION}

Communication is a tool in order to help people around the world to interact with each other. According to (Quyen \& Loi, 2018), communication only occurs when two associated informations processed each other. In this case, the speaker communicated with each other or the audience in order to express their emotions by using words, facial expressions and gestures.

There are two forms of communications namely verbal communication and nonverbal communication (Eunson, 2015). Quite away, many people assumed that verbal communication is more relevant than nonverbal communication (Johnstone \& Selepeng, 2001). Most people believed that verbal communication is more relevant because it is performed orally and easier to understand than nonverbal communication by using signs or modes (gesture, hand movement, eye contact, etc.). However, according to Norris 
(2004), the use of verbal communication and nonverbal communication is relevant and could be combined. The use of nonverbal communication could emphasize the meaning of verbal communication. This combination of both verbal communication and nonverbal communication in a conversation is called multimodal communication (Norris, 2004).

According to Norris (2004), during the conversation that happened between the speaker and the interlocutor, they are not only concern about the spoken language, but rather with the gesture, facial expression and eyes contact. Basically, in the conversation by the speaker and the interlocutor, the modes of spoken language, gesture, gaze, hand movement, facial expression occurred simultaneously or alternately and this action is called higher-level actions (Norris, 2004). This matter depend on the communication's culture of the people doing it. The focus of this study is analyzing the implementation of higher-level actions of six waiters including the waitress at three restaurants in Tabanan Regency, Bali Province and investigating the functions of higher-level actions applied by the waiters and waitress when serving the foreign guests.

In analyzing the multimodality in communication, the multimodal researcher should be able to capture the contextual meaning of someone's utterance (Krees and Van Leewuen, 2006). Multimodal communication researchers are highly interested in the role that language played in social life based on the cultures of the speakers and interlocutors (Norris, 2004). Therefore, to analyze the multimodal communication, the researcher have to investigate the communication's role of the people when interacting with others in real situations (Norris, 2004). There are three levels that could be analyzed by the multimodal researcher in analyzing the multimodal communication namely lower-level action, higher-level action, and frozen action (Norris, 2004).

Lower-level action is the smallest pragmatic meaning units of communicative modes, such as an utterance for spoken language, a gesture unit for the mode of gesture, or a postural shift for the mode of posture (Norris, 2004). These lower-level units are interested to multimodal interaction analysis as they allowed for micro-analyses.

Higher-level action is the process of how the verbal and nonverbal communication produced simultaneously or alternately in a conversation between the speaker and the interlocutor (Norris, 2004). Higher-level actions are made up of an abundance of chains of lower-level actions, for example, a conversation was made up of chains of spoken language, chains of gestures, chains of postural shifts, and so on. While a higher-level action such as a conversation is produced through these chains of lower-level actions of spoken language, gestures, or postural shifts. Thus lower-level and higher-level actions combine each other.

Frozen action is actions entailed in objects and the environment (Norris, 2004). For example, the action of building is frozen in a house, or the action of making coffee is entailed in the cup of coffee itself, just as the action of producing a software program is embedded in the actual software program.

There are some previous studies on multimodal communication that the other researchers have done. For instance, Nagao \& Takeuchi, (1994) conducted a study entitled "Speech Dialogue with Facial Display: Multimodal Human-Computer Conversation". Busso (2008) conducted a study entitled "Multimodal Analysis of Expressive Human Communication: Speech and Gesture Interplay". Dogan (2010) 
conducted a multimodal communication analysis of preschool children. Hermawan (2012) conducted a study entitled "Multimodality: Menafsir Verbal, Membaca Gambar, dan Memahami Teks". Norris (2016) conducted a study entitled "Concepts in Multimodal Discourse Analysis With Examples From Video Conferencing". Suandi \& Indriani (2016) conducted a study entitled "Tindak Komunikasi Verbal dan Nonverbal Bentuk Lepas Hormat dalam Bahasa Bali", this is a kind of Multimodal analysis of communication acts of Balinese speakers' loosely respective forms. Another research about multimodality was done by Marsakawati et al. (2019) which analyzed multimodal study entitled "An Indonesian EFL Learner's Use of Evaluative Language and Gesture in a Spoken Persuasive Presentation".

Especially for this study, the researcher analyzed the higher-level actions that applied by the waiters and waitresses at three restaurants in Tabanan Regency, Bali Province. The higher-level action is the important unit in this analysis seen from the manner of waiters or waitresses' communication that used English as their foreign language to the foreign guests. In this study, the higher-level action had been analyzed by the researcher as Engllish Language Education student, who had to analyzed the way of the social actors communicated each others in the real situation.

Because of this matter, especially in this study, it became an interesting matter by the researcher at analyzing the higher-level actions of Indonesian people especially the Balinese people when communicating with foreign guests. This study analyzed the higher-level actions of waiters or waitresses who working in Bali's local restaurants, especially in Tabanan Regency. The reasons were most waiters or waitresses who working in the local restaurants were local people who used English as their international language when communicating with foreign guests from various countries. Waiter or waitress is someone who served food and drinks in a restaurant, and also a restaurant employee who waiting for the presence of restaurant guests (Kartika, 2010). They should give clear informations to the foreign guest. This study also investigated the functions of higher-level actions of multimodal communication by the waiters or waitresses in serving foreign guests.

\section{METHOD}

The design of this study was a descriptive qualitative research. Descriptive qualitative as a researchwas restricted to factual registration. The descriptive qualitative study was not forming hypotheses or developing theory, but it was described the reality (Creswell, 2012)

This study described the higher-level actions performance of waiters or waitresses at three restaurants in Tabanan. Three restaurants in Tabanan were being the locations to get the data of this study because of those were several favorite restaurants for foreign guests in Tabanan. Another reason was because the waiters or waitresses were local people who spoke English as their foreign language. This descriptive qualitative analysis was used to describe the performances of waiters or waitresses in applying the higherlevel actions in serving the foreign guests and also to find out the functions of higherlevel actions of the waiters or waitresses in serving the foreign guests. 
In this study, the object of this study was the higher-level actions (Norris, 2004), where the verbal and nonverbal communications used by the waiters or waitresses who working at three restaurants in Tabanan.

The researcher did an observation as the researcher's academic interest. The data were collected through observation and interviewed the waiters or waitresses at three restaurants in Tabanan. It was done in order to gain the data through observed the communication process or the interaction between the waiters or waitresses and foreign guests. After doing observation and being transcribed, the researcher interviewed the waiters or waitresses to find out the functions of applying their nonverbal communication in their spoken language.

This study was guided by the research questions of the study; how the performances of the waiters or waitresses in applying the higher-level actions in serving the foreign guests and what are the functions of using higher-level action of the waiters or waitresses when serving the foreign guests. After collecting the data, the process was analyzing the data used a concept proposed by Fishman (1972) cited in Suandi \& Indriani (2016) about the role of verbal and nonverbal communication to Norris (2004) about concept of higher-level action.

\section{FINDINGS AND DISCUSSION}

All data obtained by the researcher were included in the higher-level actions because of all waiters and waitresseses made two kinds of communications such as verbal and nonverbal at the same time or alternately (Norris, 2004).

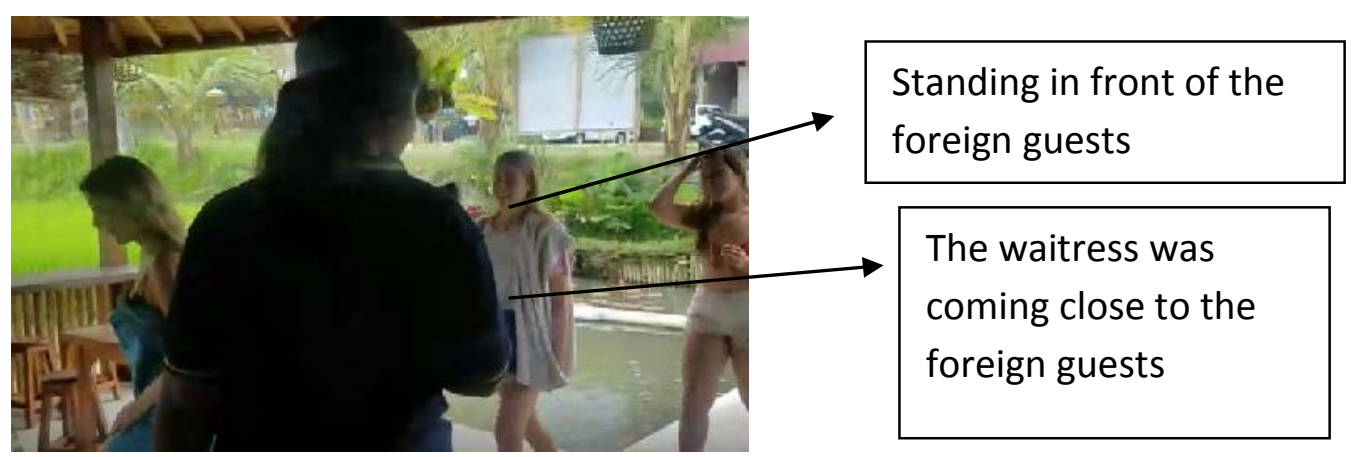

Figure 1. The Higher-Level Actions of The Waitress in Welcoming The Guests

The welcoming action of the waitress in figure 1 above showed that the waitress was coming close to the guests and simultaneously communicated with the foreign guests. There were two modes that used by the waitress, such as spoken language (greeting), and posture (coming close to the foreign guests and standing in front of the foreign guests). In this case, the waitress paid close attention and she was highly aware of the higher-level action that she constructed to the foreign guests. When the guests came to the restaurant, the waitress welcomed the guests by said "Welcome!" the spoken language (greeting) was used in order to welcome the foreign guests' arrival. The use of spoken language was used simultaneously with the mode of posture (coming close to the foreign guests). The waitress was coming close to the foreign guests in order to show her friendliness and politeness as an Indonesian people to the guests. 


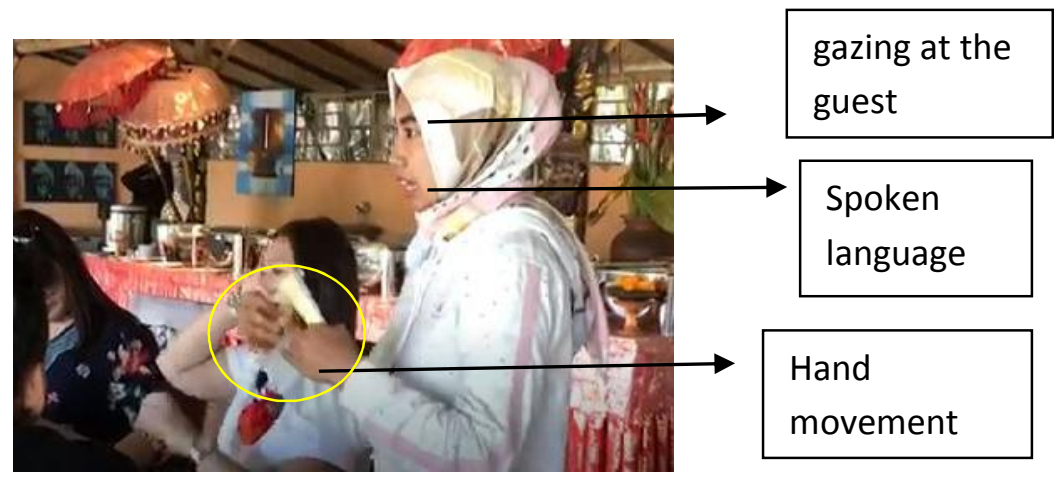

Figure 2. The Higher-Level Actions of The Waitress in Giving Informations to the Guests

In figure 2, the waitress showed her higher-level actions when explaining the food to the foreign guests. The foreign guests asked about "bapakmi" which was one of special food in the restaurant. Then, the waitress explained the food by using several modes simultaneously to the foreign guests such as, spoken language, eyes contact, and gesture (hand movement). The waitress explained the food by said "eee seafod, with prawn, calamari mix in the rice". At the same time, the waitress gazed at the foreign guests in order to make a good connection with theforeign guests during she explained the food. Then, the waitress also used a hand movement during explained the food to the foreign guests. The waitress was moved her hands when said an utterance "mix in the rice". She showed her hands (in figure 2) in order to emphasized her information, so the guests can believe and understand with her information.

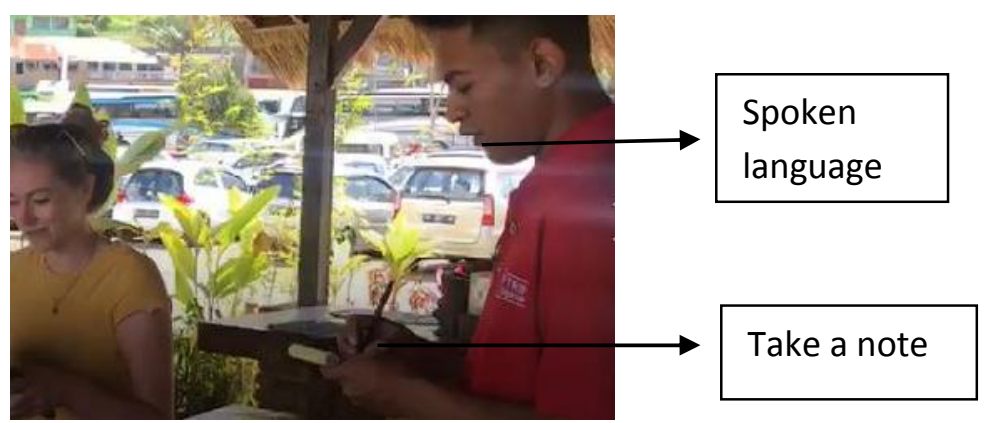

Figure 3. The Higher-Level Actions of the Waitress in Taking Order

The higher-level actions from the waiter in taking order action can be seen in figure 3. The waiter used his higher-level actions simultaneously at the moment such as spoken language and gesture. The waiter used spoken language mode by said "mie goreng, oke". The waiter recalled or confirmed the order from the foreign guests in order to ensure the order from the foreign guests. The used of the spoken language was used simultaneously with the use of gesture (took a note the order).

After collecting the data, the researcher did interview waiters and waitresses at three restaurants who had being observed. The data were analyzed and investigated in order to find out the functions of the waiters or waitresses to combine the verbal and nonverbal communication in serving the foreign guests. The table below showed the functions of the waiters or waitresses to combine their verbal and nonverbal communication in serving the foreign guests. 
Table 1. The Functions of Higher-Level Actions by the Waiters and Waitress

\begin{tabular}{cll}
\hline No & \multicolumn{1}{c}{ Functions } & \multicolumn{1}{c}{ Context } \\
\hline 1 & $\begin{array}{l}\text { - It made thewaiters or waitresses } \\
\text { feel convince or confident to use } \\
\text { verbal and nonverbal } \\
\text { communications simultaneously or } \\
\text { alternately in serving the foreign } \\
\text { guets. }\end{array}$ & $\begin{array}{l}\text { The waiter or waitresses were } \\
\text { convinced to serve and accept } \\
\text { the guests order }\end{array}$ \\
\hline 2 & $\begin{array}{l}\text {-It made their messages given to the } \\
\text { foreign guests clearer } \\
\text {-the guests would be more focus on } \\
\text { the explanation }\end{array}$ & $\begin{array}{l}\text { The informations would be } \\
\text { easier to understand for the } \\
\text { foreign guests }\end{array}$ \\
\hline 3 & $\begin{array}{l}\text {-It made the foreign guests believed } \\
\text { with the waiters' messages }\end{array}$ & $\begin{array}{l}\text { The waiters or waitresses can } \\
\text { attrack the foreign guests } \\
\text { believed } \\
\text { informations }\end{array}$ \\
& & \\
& &
\end{tabular}

Table 1 was the most functions of the waiters or waitresses that found by the researcher from interview section. Based on the functions of the waiters or waitresses to combine the verbal and nonverbal communication in serving the foreign guests above, it can be concluded that there were three main functions in applying verbal and nonverbal communications simultaneously or alternately in serving the foreign guests.

First, it made the verbal and nonverbal communication being more equal and compatible. It made the waiters felt comfort to communicate to the foreign guest based on the situation. Second, it made the verbal and nonverbal communication of the staff clearer. The point was the message of the waiter would be understood by the foreign guest. The last was using verbal and nonverbal simultaneously can emphasized the message or information of the waiters. In the other hand, the foreign guests believed on the staff's message.

\section{CONCLUSION AND SUGGESTION}

Based on the finding and discussion that were presented before, it could be concluded that; There were several higher-level actions which were applied by the waiters or waitresses in serving the foreign guests. They applied their higher-level actions in every service that given to the foreign guests. The waiters or waitresses were aware to construct the higher-level actions in their communications in every service to the foreign guests.

There were three main functions of the waiters or waitresses to use the higherlevel actions in serving the foreign guests. First, it made the verbal and nonverbal communication being more equal and compatible in their conversation with the foreign guests. When they delivered their message verbally, it's incomplete without using several 
nonverbal communications based on the context. Second, it made the verbal and nonverbal communication of the waiters clearer. The point was the message of the waiters or waitresses would be understood by the guests and the guests also being more focused on the waiters or waitresses' message. The last was using verbal and nonverbal simultaneously or alternately can emphasize the message or information of the waiters. In the other hand, the foreign guests believed on the waiters or waitresses' message.

In line with conclusion above, some suggestion can be proposed to teachers, other researchers, and English Language Students. The result of this study might be used as a reference to English Language Education of Undiksha when there are further researchers that would conduct a research about multimodal communication. Also, this study could be useful for the students to give them information about how the communication produced by verbal and nonverbal and could be understood by the interlocutor. This study was limited to the analysis of multimodal communication in the waiter performance in applying the higher-level actions in serving the foreign guests. The researcher of this study expects for the other researchers to conduct a deeper study in similar places or in other places in identifying the multimodal communications in different levels to improve the knowledge for other people. This study could be a guidance for the future study especially in analyzing the concept of multimodal communication in the real situation. This study also could be a learning material for all students who interested to learn multimodal communication.

\section{REFERENCES}

Busso, C. (2008). Multimodal Analysis of Expressive Human Communication: Speech and Gesture Interplay. August.

Dogan, Z. (2010). Florida State University Libraries Preschool Children's Multimodal Meaning Making: Verbal and Nonverbal Comunication within Two Different Clasroom Settings.

Eunson, B. I. (2015). Non-Verbal Communication. June 2012.

Hermawan, B. (2012). Multimodality: Menafsir Verbal, Membaca Gambar, dan Memahami Teks.

Johnstone, A. H \& Selepeng, D. (2001). Alex H JOHNSTONE 1 and Ditshupo SELEPENG 2 1.2(1), 19-29.

Kartika, A. (2010). The Job Descriptions of Waiter / Waitress in Food and Beverage Department in Lor In Hotel FACULTY OF LETTERS AND FINE ARTS.

Marsakawati, N. P. E., Mujiyanto, J., Agustien, H. I. R., \& Astuti, P. (2019). An Indonesian EFL learner's use of evaluative language and gestures in a spoken persuasive presentation: A case study. Journal of Asia TEFL, 16(1), 401-410. https://doi.org/10.18823/asiatefl.2019.16.1.30.401

Nagao \& Takeuchi (1994). Akikazu Takeuchi Research Overview of Multimodal Dialogues Facial Displays as a New Modality Incorporating Facial Displays into a Speech Dialogue System. System.

Norris, S. (2013). Multimodal Communication: $\quad$ Overview. https://doi.org/10.1002/9781405198431.wbeal1345 
Norris, S. (2016). Concepts in multimodal discourse analysis with examples from video conferencing. 2, 141-165. https://doi.org/10.1515/yplm-2016-0007

Quyen, T. T. T., \& Loi, N. V. (2018). Flipped model for improving students' English speaking performance. Can Tho University Journal of Science, 54(2)(January), 90. https://doi.org/10.22144/ctu.jen.2018.012

Saville-troike, M. (n.d.). The Ethnography of Communication.

Suandi, I. N. \& Indiraini, M. S. (2016). Tindak Komunikasi Verbal dan Nonverbal Bentuk Lepas Hormat dalam Bahasa Bali. 06(April), 37-58. 